\title{
Mucin biosynthesis
}

\section{Properties of a bovine tracheal mucin $\boldsymbol{\beta}-6-\mathrm{N}$-acetylglucosaminyltransferase}

\author{
Pi-Wan CHENG, ${ }^{*} \dagger$ William E. WINGERT, $\ddagger$ Mark R. LITTLE* and Robert WEI $\ddagger$ \\ *Department of Pediatrics and $†$ Department of Biochemistry, University of North Carolina at Chapel Hill, \\ Chapel Hill, NC 27514, U.S.A., and $\ddagger$ Department of Chemistry, Cleveland State University, Cleveland, \\ OH 44115, U.S.A.
}

\section{(Received 23 August 1984/Accepted 11 December 1984)}

\begin{abstract}
We have characterized a bovine tracheal mucin $\beta-6-N$-acetylglucosaminyltransferase that catalyses the transfer of $N$-acetylglucosamine from UDP- $N$-acetylglucosamine to the C-6 of the $N$-acetylgalactosamine residue of galactosyl- $\beta 1 \rightarrow 3-N$-acetylgalactosamine. Optimal enzyme activity was obtained between $\mathrm{pH} 7.5-8.5$, at $5 \mathrm{mM}-\mathrm{MnCl}_{2}$, and at $0.06-0.08 \%(\mathrm{v} / \mathrm{v})$ Triton X-100 (or Nonidet P-40), or 0.5-5.0\% (v/v) Tween 20. $\mathrm{Ba}^{2+}, \mathrm{Mg}^{2+}$ and $\mathrm{Ca}^{2+}$ could partially replace $\mathrm{Mn}^{2+}$, but $\mathrm{Co}^{2+}, \mathrm{Fe}^{2+}, \mathrm{Cd}^{2+}$ and $\mathrm{Zn}^{2+}$ could not. Sodium dodecyl sulphate, cetylpyridinium chloride, sodium deoxycholate, octyl $\beta$-D-glucoside, digitonin and alkyl alcohols were less effective in enhancing enzyme activity, and dimethyl sulphoxide was ineffective. The apparent Michaelis constants were $1.25 \mathrm{mM}$ for UDP- $N$-acetylglucosamine, $0.94-3.34 \mathrm{mM}$ for freezingpoint-depressing glycoprotein and $0.19 \mathrm{~mm}$ for periodate-treated blood-group-A porcine submaxillary mucin. Asialo ovine submaxillary mucin could not serve as the glycosyl acceptor. The structure of the ${ }^{14} \mathrm{C}$-labelled oligosaccharide obtained by alkaline-borohydride treatment of the product was identified as $\mathrm{Gal} \beta 1 \rightarrow 3(\mathrm{Glc}$ $\mathrm{NAc} \beta 1 \rightarrow 6) N$-acetylgalactosaminitol by $\beta$-hexosaminidase treatment, gas chromatography-mass spectrometry and ${ }^{1} \mathrm{H}$-n.m.r. $(270 \mathrm{MHz})$ analysis. The enzyme is important in the regulation of mucin oligosaccharide biosynthesis.
\end{abstract}

Mucous glycoprotein (mucin) is a major determinant of the rheological properties of mucus secretion (Allen, 1978; Rose et al., 1979). The carbohydrate moiety of mucous glycoprotein constitutes $50-80 \%$ of the molecule by weight (Boat \& Cheng, 1976). Carbohydrate can contribute to the aggregation of mucin (Hill et al., 1977), which in turn could affect the rheological properties of mucus secretion. Mucin oligosaccharide chains, which are heterogeneous in nature, are synthesized by the

Abbreviations used : asialo-OSM, ovine submaxillary mucin (OSM) treated with neuraminidase and $\beta$-galactosidase (Cheng \& Bona, 1982); $\mathrm{IO}_{4}^{-}{ }^{-}$-PSM, blood-group-A porcine submaxillary mucin (PSM) treated with periodate (Wingert \& Cheng, 1984); FPDG, freezing-pointdepressing glycoprotein; NeuGc (in sequences), $N$ glycollylneuraminic acid; GalNAc- $\mathrm{H}_{2}$ (in sequences), $\mathrm{N}$ acetylgalactosaminitol.

† To whom correspondence should be addressed, at: 635 Clinical Sciences Building 229H, Department of Pediatrics, University of North Carolina at Chapel Hill, Chapel Hill, NC 27514, U.S.A. sequential addition of sugar from sugar nucleotide to the acceptor (Roseman, 1970). Thus the sequence of sugar addition determines the final oligosaccharide structure (Beyer et al., 1981). Following the transfer of the first sugar, $N$-acetylgalactosamine to serine/threonine in the peptide, one of the three sugars galactose, $\mathrm{N}$-acetylglucosamine (Lamblin et al., 1981) and $N$-acetylneuraminic acid may be added to the $N$-acetylgalactosamine residue. If NeuAc $\alpha 2 \rightarrow 6 \mathrm{GalNAc}$ is formed first, synthesis of the oligosaccharide will be terminated at the disaccharide level (Carlson et al., 1973; Beyer et al., 1979). However, if $\mathrm{Gal} \beta 1 \rightarrow$ $3 \mathrm{GalNAc}$ or GlcNAc $\beta 1 \rightarrow 3 \mathrm{GalNAc}$ is formed, then, depending on whether a chain-elongation sugar, e.g. galactose or $\mathrm{N}$-acetylglucosamine, or a chain-terminating sugar, e.g. $N$-acetylneuraminic acid or L-fucose, is added, the oligosaccharide chain synthesis could either continue or be limited (Schachter, 1978; Beyer et al., 1981).

Increase in oligosaccharide chain length has been reported for tracheal (Lamblin et al., 1977) as 
well as intestinal (Wesley et al., 1983) mucins from patients with cystic fibrosis. Studies of the key enzymes involved in the regulation of tracheal mucin oligosaccharide synthesis may yield some important insight into the possible causes for this alteration. The present paper describes a bovine tracheal mucin $\mathrm{N}$-acetylglucosaminyltransferase activity that catalyses the following reaction: (expressed as available Gal-GalNAc sites) of FPDG and $50-200 \mu \mathrm{g}$ of enzyme protein. The UDP- $\left[{ }^{14} \mathrm{C}\right]-N$-acetylglucosamine was prepared by diluting the UDP-[U-14 $\mathrm{C}]-N$-acetylglucosamine $(49 \mathrm{mCi} / \mathrm{mmol})$ obtained from the New England Nuclear Corp. (Boston, MA, U.S.A.) with unlabelled UDP- $N$-acetylglucosamine (Sigma Chemical Co., St. Louis, MO, U.S.A.). The reaction

UDP-GlcNAc + Gal $\beta 1 \rightarrow 3$ GalNAc $\alpha \mathrm{Thr} \longrightarrow$ Gal $\beta 1 \rightarrow 3($ GlcNAc $\beta 1 \rightarrow 6)$ GalNAc $\alpha$ Thr + UDP

\section{Experimental}

\section{Preparation of microsomal fraction from bovine tracheal epithelium}

Epithelial scrapings from bovine tracheas obtained fresh from a local slaughterhouse were homogenized ( 12 strokes) in 4 vol. of $0.25 \mathrm{M}$-sucrose with a glass homogenizer. The microsomal fraction (Wingert \& Cheng, 1984) was resuspended in $0.25 \mathrm{M}$-sucrose, approx. one-tenth the volume of the original homogenate, and then stored at $-20^{\circ} \mathrm{C}$. About half of the enzyme activity remained after 1 year.

\section{Preparation of acceptors}

OSM and PSM were prepared from sheep and pig submaxillary glands (Pel Freez Biological, Rogers, AR, U.S.A.) respectively, by the procedure of de Salegui \& Plonska (1969). AsialoOSM was prepared by the treatment of OSM with neuraminidase and bovine testicular $\beta$-galactosidase as previously described (Cheng \& Bona, 1982). $\mathrm{IO}_{4}^{-}-\mathrm{PSM}$ was prepared by treating PSM $(2 \mathrm{mg} / \mathrm{ml})$ with $20 \mathrm{~mm}-\mathrm{NaIO}_{4}$ as described previously (Wingert \& Cheng, 1984). The $\mathrm{IO}_{4}^{-}-\mathrm{PSM}$ contained no detectable amounts of fucose and sialic acid, and the ratio of $N$-acetylgalactosaminitol to $\mathrm{Gal} \beta 1 \rightarrow 3 \mathrm{GalNAc}-\mathrm{H}_{2}$ was found to be approx. $3: 2$. FPDG was isolated from the serum of an antarctic fish, Dissostichus mawsoni, by DEAEcellulose column chromatography by using the procedure of Lin \& DeVries (1974). The fraction eluted with $2.5 \mathrm{~mm}$-Tris $/ \mathrm{HCl}$, which contains FPDG fractions 1-5, was used as the acceptor to carry out the studies except for the acceptor competition study, where FPDG fractions 7 and 8 (DeVries et al., 1970) were used.

\section{Enzyme assays}

The assay mixture in a total volume of $50 \mu \mathrm{l}$ contained $5 \mu \mathrm{l}$ of $0.5 \mathrm{M}$-Mops adjusted to $\mathrm{pH} 7.5$ with $1 \mathrm{M}-\mathrm{NaOH}, 5 \mu \mathrm{l}$ of $0.8 \%(\mathrm{v} / \mathrm{v})$ Triton $\mathrm{X}-100,5 \mu \mathrm{l}$ of $50 \mathrm{mM}-\mathrm{MnCl}_{2}, 5 \mu \mathrm{l}$ of $50 \mathrm{~mm}-\mathrm{ATP}$ adjusted to pH 7.5 with $1 \mathrm{M}-\mathrm{NaOH}, 5 \mu \mathrm{l}$ of $20 \mathrm{mM}-\mathrm{UDP}-\left[{ }^{14} \mathrm{C}\right]-$ $N$-acetylglucosamine $(0.7 \mathrm{mCi} / \mathrm{mmol}), 5 \mu 1$ of bovine serum albumin solution $(10 \mathrm{mg} / \mathrm{ml}), 4.5 \mu \mathrm{mol}$ mixture was incubated at $37^{\circ} \mathrm{C}$ for $60 \mathrm{~min}$, and the reaction was stopped by the addition of $0.4 \mathrm{ml}$ of ice-cold $1 \mathrm{M}-\mathrm{NaCl}$ solution containing Methyl Red to monitor the column performance. The ${ }^{14} \mathrm{C}$-labelled product was isolated by chromatography on Bio-Gel P-4 columns $(29 \mathrm{~cm} \times 1 \mathrm{~cm})$ as previously described (Cheng \& Bona, 1982). Average values of the results of duplicate samples after subtracting those of the controls, which contained no acceptor, are expressed as $\mathrm{nmol}$ of $N$-acetylglucosamine transferred/h per mg of protein. Protein was assayed by the method of Lowry et al. (1951), with bovine serum albumin as the standard. All enzyme assays were performed under conditions where product formation was linear with respect to incubation times and enzyme amounts.

\section{Preparation of ${ }^{14} \mathrm{C}$-labelled product and isolation of} the trisaccharide

A large-scale preparation of the ${ }^{14} \mathrm{C}$-labelled product was carried out by incubating the following mixture in a final volume of $1 \mathrm{ml}$ : Mops buffer, $\mathrm{pH} 7.5,50 \mu \mathrm{mol}$; Triton X-100 $(0.8 \%$, v/v), $100 \mu 1$; bovine serum albumin, $1 \mathrm{mg} ; \mathrm{MnCl}_{2}, 3 \mu \mathrm{mol}$; FPDG, $20 \mathrm{mg}$; UDP- $\left[{ }^{14} \mathrm{C}\right]-N$-acetylglucosamine (900d.p.m./nmol), $6 \mu \mathrm{mol}$; ATP, $5 \mu \mathrm{mol}$; 2,3-dimercaptopropanol (Faltynek et al., 1981), $5 \mu \mathrm{mol}$; $10.4 \mathrm{mg}$ of enzyme protein; 2 drops of toluene. After incubation at $37^{\circ} \mathrm{C}$ for $14 \mathrm{~h}$, the ${ }^{14} \mathrm{C}$-labelled product was isolated by chromatography on BioGel P-4. Oligosaccharides were removed from the ${ }^{14} \mathrm{C}$-labelled product under alkaline borohydride conditions (Carlson, 1968). The ${ }^{14} \mathrm{C}$-labelled oligosaccharide was subsequently purified by chromatography on a Bio-Gel P-2 (-400 mesh) column $(2.5 \mathrm{~cm} \times 180 \mathrm{~cm})$ that had previously been calibrated with galactose, lactose, $N$-acetylglucosamine, $\mathrm{Gal} \beta 1 \rightarrow 3 \mathrm{GalNAc}-\mathrm{H}_{2}$ (Cheng \& Bona, 1982), Fuc $\alpha 1 \rightarrow 2 \mathrm{Gal} \beta 1 \rightarrow 3 \mathrm{GalNAc}-\mathrm{H}_{2}$ (Carlson, 1968), raffinose and stachyose (Pfanstiehl Laboratories, Wankegan, MI, U.S.A.).

Preparation of partially methylated alditol acetates from the trisaccharide

Permethylation of the trisaccharide was carried out by the method of Hakomori (1964). Approx. 
$480 \mathrm{nmol}$ of the trisaccharide was treated with anhydrous dimethyl sulphoxide anion for $2 \mathrm{~h}$ and then methylated with methyl iodide overnight. After the addition of $10 \mathrm{ml}$ of chloroform, dimethyl sulphoxide was removed by extraction with an equal volume of water. The chloroform layer was extracted three more times with water and then dried under $\mathrm{N}_{2}$. The samples were then subjected to acetolysis, reduced with $\mathrm{NaB}^{2} \mathrm{H}_{4}$ (Merck, Sharp and Dohme, Rahway, NJ, U.S.A.) and acetylated with acetic anhydride as previously described (Stellner et al., 1973).

Gas-chromatography and gas-chromatographymass-spectrometry analysis of the partially methylated alditol acetates

The partially methylated alditol acetates were separated isothermally at $180^{\circ} \mathrm{C}$ on a $3 \% \mathrm{OV}$ 225 glass column $(1.8 \mathrm{~m} \times 2 \mathrm{~mm})$ using a Hewlett-Packard model $5800 \mathrm{~A}$ gas chromatograph equipped with a flame ionization detector. The column was standardized with the following alditol acetates: 1,5-diacetyl-2,3,4,6-tetramethylglucitol prepared from $\alpha$-methyl glucopyranoside, 1,5diacetyl-2,3,4,6-tetramethylgalactitol and 1,4,5triacetyl-2,3,6-trimethylglucitol prepared from lactose, and 3-acetyl-1,4,5,6-tetramethyl-2- $N$ methylacetamidogalactitol prepared from Gal $\beta$ $1 \rightarrow 3$ GalNAc- $\mathrm{H}_{2}$ by Hakomori's (1964) procedure. Mass spectra were then taken on a HewlettPackard 5958A gas chromatograph-mass spectrometer at the mass-spectrometry facility, Department of Biochemistry, Michigan State University, East Lansing, MI, U.S.A.) (Wingert \& Cheng, 1984).

\section{$\beta$-Hexosaminidase treatment of the trisaccharide}

Treatment of the trisaccharide with the jackbean $\beta$-hexosaminidase (Li et al., 1975) was carried out with a $25 \mu \mathrm{l}$ reaction mixture containing $48 \mathrm{nmol}$ of ${ }^{14} \mathrm{C}$-labelled trisaccharide, $50 \mu \mathrm{g}$ of bovine serum albumin, $30 \mathrm{~mm}$-citric acid $/ 80 \mathrm{~mm}$ $\mathrm{Na}_{2} \mathrm{HPO}_{4}, \mathrm{pH} 4.3,5.2$ units of jack-bean $\beta$-hexosaminidase and 1 drop of toluene. The reaction mixture was incubated for $16 \mathrm{~h}$ at $37^{\circ} \mathrm{C}$ and then applied to a Bio-Gel P-2 ( -400 mesh) column $(2.5 \mathrm{~cm} \times 180 \mathrm{~cm})$ to separate the reactant from the products.

\section{${ }^{1} H$-n.m.r. studies}

The ${ }^{1} \mathrm{H}$-n.m.r. spectrum of the trisaccharide $(0.7 \mu \mathrm{mol})$ was obtained on a Bruker $270 / 180$ Fourier-transform n.m.r. spectrometer operating at $270 \mathrm{MHz}$. After the repeated exchange of hydrogen with $99.8 \%{ }^{2} \mathrm{H}_{2} \mathrm{O}$ (KOR Isotopes, Cambridge, MA, U.S.A.), the trisaccharide was dissolved in $0.1 \mathrm{ml}$ of $99.8 \%{ }^{2} \mathrm{H}_{2} \mathrm{O}$ and transferred to a $5 \mathrm{~mm}$ probe. Acetone, which has a chemical shift of 2.225 p.p.m. from tetramethylsilane, was included as a secondary internal standard. The data were acquired as described previously (Wingert \& Cheng, 1984).

H.p.l.c. analysis of unmodified trisaccharide and benzoylated trisaccharide

Unmodified oligosaccharides were analysed on a primary-amine column $(25 \mathrm{~cm} \times 4.6 \mathrm{~mm})$ with a linear gradient of $85 \%(\mathrm{v} / \mathrm{v})$ acetonitrile in water to $60 \%(\mathrm{v} / \mathrm{v})$ acetonitrile in water by the method of Lamblin et al. (1981). Oligosaccharides were monitored by the absorbance at $206 \mathrm{~nm}$ with a Varian UV-50 detector.

The trisaccharide isolated from bovine tracheal enzyme product and $\mathrm{Gal}-\mathrm{GalNAc}-\mathrm{H}_{2}, \mathrm{~N}$-acetylgalactosaminitol and $\mathrm{NeuAc} \alpha 2 \rightarrow 6 \mathrm{GalNAc}-\mathrm{H}_{2}$ were perbenzoylated by using the procedure of Daniel et al. (1981). The benzoylated derivatives were chromatographed on an Ultrasphere-Octyl column $(4.6 \mathrm{~mm} \times 25 \mathrm{~cm})$ with a linear gradient of $70 \%(\mathrm{v} / \mathrm{v})$ acetonitrile in water to $100 \%(\mathrm{v} / \mathrm{v})$ acetonitrile. Oligosaccharide derivatives were monitored by the absorbance at $230 \mathrm{~nm}$.

\section{Results}

\section{Requirements for enzyme activity}

A 6-7-fold enhancement of enzyme activity was observed when $0.06-0.08 \%(v / v)$ Triton X-100 or Nonidet was included in the assay mixture (Fig. 1). High concentrations $(\geqslant 0.5 \%)$ of Tween 20 and even higher concentrations $(\geqslant 10 \%)$ of Tweens 80 and 60 were needed to give approximately the same effect. At $5 \mathrm{~mm}$ concentration of $\mathrm{Mn}^{2+}$, enzyme activity was enhanced maximally by $70 \%$. At concentrations higher than $15 \mathrm{mM}, \mathrm{Mn}^{2+}$ was inhibitory. However, enzyme activity was not affected by the addition of $20 \mathrm{mM}$-EDTA in the absence of $\mathrm{Mn}^{2+}$. $\mathrm{Ca}^{2+}, \mathrm{Mg}^{2+}$ and $\mathrm{Ba}^{2+}$ enhanced enzyme activity by $26-55 \%$. $\mathrm{Co}^{2+}$ did not affect enzyme activity, and $\mathrm{Fe}^{2+}, \mathrm{Cd}^{2+}$ and $\mathrm{Zn}^{2+}$ inhibited enzyme activity by $40 \%, 75 \%$ and $100 \%$ respectively. Optimal enzyme activity was observed at pH 7.5-8.5 with Mops buffer. Spermidine at $2 \mathrm{mM}$ increased the enzyme activity by $13-17 \%$. The apparent Michaelis constants obtained under the conditions given in the Experimental section for UDP- $N$-acetylglucosamine, FPDG fractions 1-5 (Lin \& DeVries, 1974), FPDG fractions 7-8 (DeVries et al., 1970) and $\mathrm{IO}_{4}^{-}-\mathrm{PSM}$ were $1.25 \mathrm{mM}$, $3.34 \mathrm{~mm}, 0.95 \mathrm{~mm}$ and $0.19 \mathrm{~mm}$ respectively. No enzyme activity was detected when asialo-OSM $(10 \mathrm{mM})$ was used as the acceptor. 


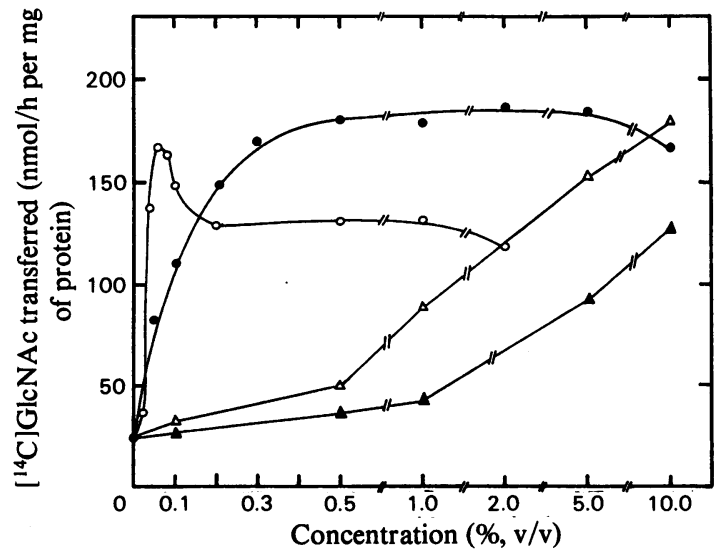

Fig. 1. Effects of type $A$ non-ionic detergents on bovine tracheal mucin $\mathrm{N}$-acetylglucosaminyltransferase activity A reaction mixture in a total volume of $50 \mu 1$ contained the following components: UDP- $\left[{ }^{14} \mathrm{C}\right]-$ $N$-acetylglucosamine $(0.7 \mathrm{mCi} / \mathrm{mmol}), 0.10 \mu \mathrm{mol}$; Mops buffer, pH 7.5, $2.5 \mu \mathrm{mol} ; \mathrm{MnCl}_{2}, 2.5 \mu \mathrm{mol}$; bovine serum albumin, $50 \mu \mathrm{g}$; ATP, $0.25 \mu \mathrm{mol}$; FPDG, $0.25 \mathrm{mg}$; microsomal membrane protein, $60 \mu \mathrm{g}$; detergents, as indicated. After incubation at $37^{\circ} \mathrm{C}$ for $60 \mathrm{~min}$, the enzyme reaction was stopped by the addition of $0.4 \mathrm{ml}$ of ice-cold $1 \mathrm{M}-\mathrm{NaCl}$ containing Methyl Red. The ${ }^{14} \mathrm{C}$-labelled product was immediately isolated by the Bio-Gel P-4 multiplecolumn method (Cheng \& Bona, 1982). The detergents used were Triton X-100 (O), Tween $20(O)$, Tween $60(\Delta)$ and Tween $80(\triangle)$.

Effects of ionic and type $B$ non-ionic detergents, organic solvents and salts

In contrast with the effects of the type A nonionic detergents (Helenius \& Simons, 1975), the ionic detergents, which included sodium dodecyl sulphate, cetylpyridinium chloride and sodium deoxycholate, gave 3-5-fold increase in enzyme activity at low $(<0.1 \%)$ concentrations but completely inhibited enzyme activity at higher $(0.5 \%)$ concentration. The type B non-ionic detergents including octyl $\beta$-D-glucoside and digitonin, on the other hand, either gave small enhancement in enzyme activity or did not affect enzyme activity at all at low $(<0.1 \%)$ detergent concentrations, but exerted a moderate (2.0-3.5-fold) increase in enzyme activity at higher $(0.5-1.0 \%)$ concentrations.

Butan-1-ol did not affect enzyme activity at $0.1 \%$ concentration, but increased enzyme activity 1.4 3.0 -fold at concentrations in the $1-5 \%$ range. Identical results were obtained for hexan-3-ol, pentan-2-ol and cyclohexanol. However, in the presence of $2 \%$ Tween 20, these alkyl alcohols became inhibitory. Under the same conditions, glycerol did not seem to affect the enzyme activity appreciably. Dimethyl sulphoxide did not affect

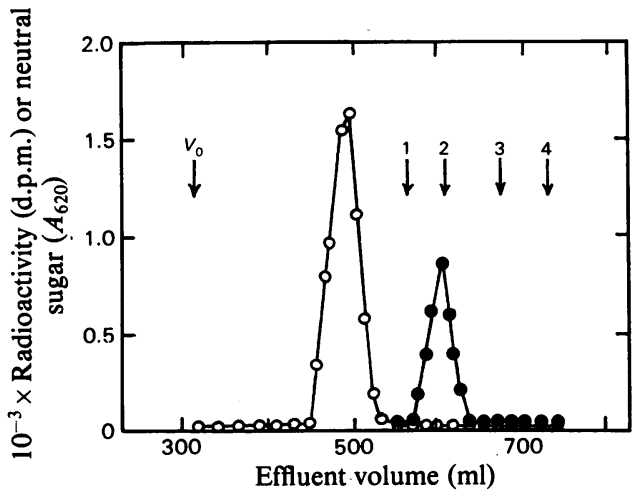

Fig. 2. Purification by Bio-Gel P-2 (-400 mesh) column $(2.5 \mathrm{~cm} \times 180 \mathrm{~cm})$ chromatography of the ${ }^{14} \mathrm{C}$-labelled oligosaccharide obtained by alkaline-borohydride treatment of the ${ }^{14} \mathrm{C}$-labelled product

The following oligosaccharides were used as standards: 1, Fuc $\alpha 1 \rightarrow 2 \mathrm{Gal} \beta 1 \rightarrow 3 \mathrm{GalNAc}-\mathrm{H}_{2} ; 2$, stachyose; 3 , raffinose; 4 , lactose. The column was eluted with distilled water at a rate of $27 \mathrm{ml} / \mathrm{h}$, and the volume of each fraction was $4.6 \mathrm{ml}$. Samples were analysed by liquid-scintillation counting $(O)$ and the anthrone assay $(O) . \mathrm{Gal} \beta 1 \rightarrow 3 \mathrm{GalNAc}-\mathrm{H}_{2}$ was co-eluted with stachyose.

the enzyme activity over a wide range (1-10\%) of concentrations when detergent was not present. In addition, enzyme activity was inhibited gradually by $\mathrm{NaCl}$ and $\mathrm{KCl}$ at increasing concentrations $(0.1-0.8 \mathrm{M})$, which was fully recoverable once the salt had been removed. In addition, $\left(\mathrm{NH}_{4}\right)_{2} \mathrm{SO}_{4}$ at $0.8 \mathrm{M}$ concentration inhibited enzyme activity to the same extent $(76 \%)$ as $\mathrm{NaCl}$ and $\mathrm{KCl}$ did.

Isolation and purification of the ${ }^{14} \mathrm{C}$-labelled trisaccharide from the product of $\mathrm{N}$-acetylglucosaminyltransferase

The ${ }^{14} \mathrm{C}$-labelled product of $\mathrm{N}$-acetylglucosaminyltransferase with FPDG as the acceptor was prepared on a large scale and isolated by chromatography on Bio-Gel P-4. About $70 \%$ of the $\left[{ }^{14} \mathrm{C}\right] \mathrm{N}$ acetylglucosamine was transferred from UDP$\left[{ }^{14} \mathrm{C}\right] \mathrm{N}$-acetylglucosamine to the acceptor. Treatment of the ${ }^{14} \mathrm{C}$-labelled product with alkaline borohydride followed by purification by chromatography on Bio-Gel P-2 yielded only one radioactive peak (Fig. 2). This elution profile suggests that only one $\mathrm{N}$-acetylglucosamine residue was added to the original disaccharide side chain of the FPDG acceptor. The trisaccharide gave only one peak, with a retention time of $43.55 \mathrm{~min}$, by h.p.l.c. on a bonded primary-amine column (Fig. 3a). This trisaccharide co-chromatographed with $\mathrm{Gal} \beta 1 \rightarrow 3(\mathrm{GlcNAc} \beta 1 \rightarrow 6)$ GalNAc- $\mathrm{H}_{2}$ (Wingert \& Cheng, 1984). Furthermore, the benzoylated derivative of the trisaccharide and that of 
$\mathrm{Gal} \beta 1 \rightarrow 3(\mathrm{GlcNAc} \beta 1 \rightarrow 6)$ GalNAc- $\mathrm{H}_{2}$ had the same retention time on a C-8 reverse-phase column (Fig. $3 b$ ).

\section{Determination of the $\mathrm{N}$-acetylglucosaminide linkage}

Gas-chromatographic analysis of the partially methylated alditol acetates prepared from the trisaccharides gave three major carbohydrate peaks under isothermal $\left(180^{\circ} \mathrm{C}\right)$ conditions. Peak 1 was co-eluted at $5.4 \mathrm{~min}$ with standard 1,5-diacetyl2,3,4,6-tetramethylgalactitol, indicating that the galactose residue is unsubstituted. Peaks 2 and 3 had relative retention times of 5.96 and 8.19 with respect to peak 1 . Since $N$-acetylglucosamine could be added to either C-4 or C-6 of the $\mathrm{N}$-acetylgalactosamine residue, confirmation of the trisaccharide structure as $\mathrm{Gal} \beta 1 \rightarrow 3(\mathrm{GlcNAc} \beta 1 \rightarrow 6) \mathrm{Gal}-$ $\mathrm{NAc}-\mathrm{H}_{2}$ was obtained by mass-spectrometric analysis of each partially methylated alditol acetate. Peak 1 gave the expected primary $\mathrm{m} / \mathrm{z}$ ion fragments of 161,162 and 205 . The ion-fragment pattern agreed with that of 1,5-diacetyl-2,3,4,6tetramethylgalactitol (Bjorndahl et al., 1967). Peak 2 had primary $m / z$ ion fragments of $45,117,159$, 161,203 and 205 , and thus was derived from unsubstituted $\mathrm{N}$-acetylglucosamine (Wrann \& Tappy, 1978). Peak 3 gave primary $\mathrm{m} / \mathrm{z}$ ion fragments of $45,117,130,161,246$ and 318 . The fragmentation pattern, which is essentially identical with that of 3,6-diacetyl-1,4,5-trimethyl-2- $N$ methylacetamidogalactitol (Wingert \& Cheng, 1984), indicates that both C-3 and C-6 are substi- tuted. Since C-3 of $\mathrm{N}$-acetylgalactosaminitol had already been occupied by galactose, $N$-acetylglucosamine had to be linked to C-6 of $N$-acetylgalactosaminitol. The ${ }^{1}$ H-n.m.r. analysis of the trisaccharide yielded essentially the same resonance spectrum as that of the standard trisaccharide $\mathrm{Gal} \beta 1 \rightarrow 3\left(\mathrm{GlcNAc} \beta 1 \rightarrow 6\right.$ ) GalNAc- $\mathrm{H}_{2}$ (Wingert \& Cheng, 1984). The resonance of galactose and $N$ acetylgalactosaminitol protons were located by the homodecoupling technique and by comparing them with the published values for $\mathrm{Gal} \beta 1 \rightarrow 3 \mathrm{Gal}-$ $\mathrm{NAc}-\mathrm{H}_{2}$ and $\mathrm{Gal} \beta 1 \rightarrow 3(\mathrm{NeuGc} \alpha 2 \rightarrow 6)$ GalNAc- $\mathrm{H}_{2}$ (Van Halbeek et al., 1981). A significant downfield shift $(0.2$ p.p.m.) was observed for one of the C- 6 protons in the $\mathrm{N}$-acetylgalactosaminitol residue of the trisaccharide as compared with that of the disaccharide, suggesting that $\mathrm{N}$-acetylglucosamine is linked to C-6 of $\mathrm{N}$-acetylgalactosaminitol.

Assignment of the anomeric configuration of the $\mathrm{N}$ acetylglucosaminide

${ }^{1} \mathrm{H}$-n.m.r. $(270 \mathrm{MHz})$ analysis of the trisaccharide showed that the coupling constant of the GlcNAc C-1 proton, which was located at 4.54 p.p.m., was $8.5 \pm 0.2 \mathrm{~Hz}$, indicating a $\beta$ anomer, since an $\alpha$-anomer would have a coupling constant of approx. $3.5 \mathrm{~Hz}$ (Van Halbeek et al., 1981). The $\beta$-configuration of the galactose $C-1$ proton was also confirmed by its coupling constant $\left(J_{1,2}=7.8 \pm 0.2 \mathrm{~Hz}\right)$ at 4.46 p.p.m. (Val Halbeek et al., 1981). Furthermore, the ratio of the peak areas of the corresponding anomeric hydrogen atoms of
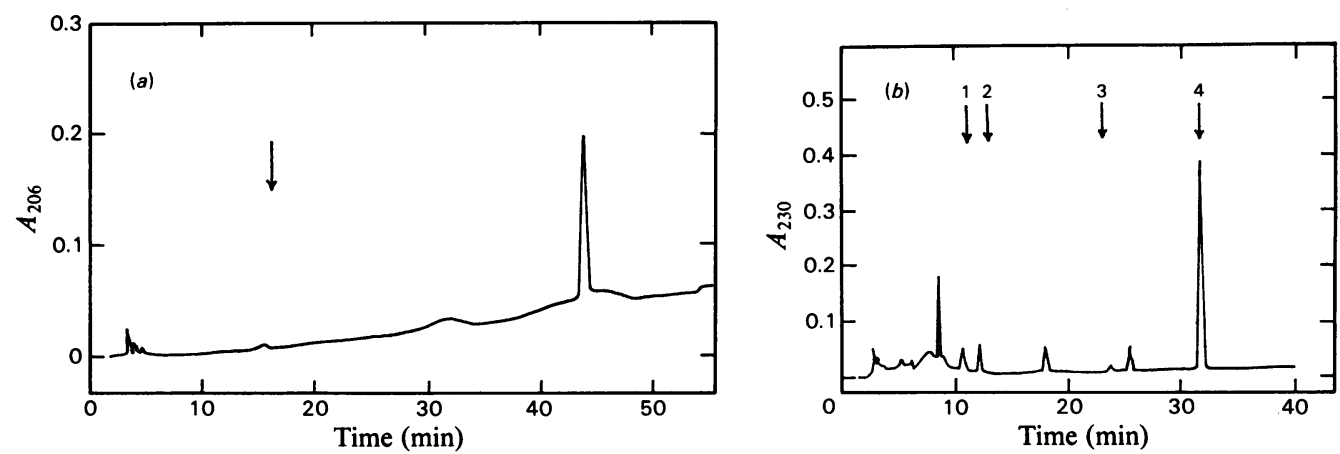

Fig. 3. H.p.l.c. elution profile of $\left(\right.$ a) the ${ }^{14} \mathrm{C}$-labelled trisaccharide $(10 \mathrm{nmol})$ obtained from alkaline-borohydride treatment of the product of bovine tracheal FPDG $\beta-6-N$-acetylglucosaminyltransferase and $(b)$ of the benzoylated derivative of the trisaccharide $(200 \mathrm{pmol})$

The bonded primary-amine ( $5 \mu \mathrm{m}$ particle size) column $(25 \mathrm{~cm} \times 4.6 \mathrm{~mm})$ was eluted with an acetonitrile gradient of $85-60 \%$ in water for $60 \mathrm{~min}$ at a flow rate of $1 \mathrm{ml} / \mathrm{min}$. The oligosaccharides were monitored by the absorbance at $206 \mathrm{~nm}$. $N$-Acetylgalactosaminitol was eluted at where the arrow is indicated. (b) The C-8 (5 $\mu \mathrm{m}$ particle size) reversed-phase column $(25 \mathrm{~cm} \times 4.6 \mathrm{~mm})$ was eluted with a gradient of $70-100 \%$ acetonitrile in water for $40 \mathrm{~min}$ at a flow rate of $1 \mathrm{ml} / \mathrm{min}$. Benzoyl derivatives were monitored by the absorbance at $230 \mathrm{~nm}$. The column was standardized with the perbenzoylated derivatives of the following oligosaccharides $(100-200 \mathrm{pmol}): 1, N-$ acetylgalactosaminitol (11.29 min); 2 , NeuAc $\alpha 2 \rightarrow 6 \mathrm{GalNAc}-\mathrm{H}_{2}(13.00 \mathrm{~min}) ; 3, \mathrm{Gal} \beta 1 \rightarrow 3 \mathrm{GalNAc}-\mathrm{H}_{2}(23.34 \mathrm{~min})$; $4, \mathrm{Gal} \beta 1 \rightarrow 3(\mathrm{GlcNAc} \beta 1 \rightarrow 6) \mathrm{GalNAc}-\mathrm{H}_{2}(31.30 \mathrm{~min})$. The retention time for the benzoylated derivative of the ${ }^{14} \mathrm{C}-$ labelled trisaccharide was $31.36 \mathrm{~min}$. 
Table 1. Acceptor competition study of bovine tracheal mucin $\beta-6-N$-acetylglucosaminyltransferase The reaction mixture $(50 \mu \mathrm{l})$ contained the following components: $\mathrm{MnCl}_{2}, 0.25 \mu \mathrm{mol}$; Mops buffer, $\mathrm{pH} 7.5,2.5 \mu \mathrm{mol}$; Triton X-100, $0.08 \%(\mathrm{v} / \mathrm{v})$; ATP, $0.25 \mu \mathrm{mol}$; bovine serum albumin, $50 \mu \mathrm{g}$; UDP- $\left[{ }^{14} \mathrm{C}\right] N$-acetylglucosamine $(0.7 \mathrm{mCi} / \mathrm{mmol}), 0.1$; enzyme protein, $75 \mu \mathrm{g}$; acceptors as indicated in the Table. The reaction was allowed to proceed at $37^{\circ} \mathrm{C}$ for $60 \mathrm{~min}$, and then the product was isolated by chromatography on a Bio-Gel P-4 column and quantified as described in the text.

\begin{tabular}{|c|c|c|c|c|c|c|}
\hline \multirow{4}{*}{$\begin{array}{l}\text { Expt } \\
\text { no. }\end{array}$} & \multirow{3}{*}{\multicolumn{2}{|c|}{ Acceptor concentration (mM) }} & \multicolumn{3}{|c|}{$\begin{array}{l}{\left[{ }^{14} \mathrm{C}\right] \mathrm{GlcN} A c \text { transferred }} \\
(\mathrm{nmol} / \mathrm{h} \text { per mg of protein })\end{array}$} & \multirow[b]{4}{*}{ Conclusion } \\
\hline & & & \multirow{3}{*}{$\begin{array}{l}\text { Experimental } \\
\text { value }\end{array}$} & \multicolumn{2}{|c|}{$\begin{array}{c}\text { Theoretical } \\
\text { value }\end{array}$} & \\
\hline & & & & \multirow{2}{*}{$\begin{array}{c}\text { One } \\
\text { enzyme }\end{array}$} & \multirow{2}{*}{$\begin{array}{l}\text { Two } \\
\text { nzymes }\end{array}$} & \\
\hline & FPDG* & $\mathrm{IO}_{4}^{--\mathrm{PSM} \dagger}$ & & & & \\
\hline 1 & 1.28 & & 22.7 & & & \\
\hline 2 & 2.55 & & 25.9 & & & \\
\hline 3 & 5.10 & & 31.4 & & & . \\
\hline 4 & & 0.29 & 8.7 & & & \\
\hline 5 & & 0.43 & 10.4 & & & \\
\hline 6 & & 0.86 & 11.8 & & & \\
\hline 7 & 1.28 & 0.29 & 22.4 & 18.8 & 31.4 & \\
\hline 8 & 2.55 & 0.43 & 22.4 & 22.4 & 36.3 & One enzyme \\
\hline 9 & 5.10 & 0.86 & 26.2 & 24.4 & 43.2 & \\
\hline
\end{tabular}

* Fractions 7 and 8 of FPDG (DeVries et al., 1970).

$\dagger$ PSM treated successively with periodate, $\mathrm{NaBH}_{4}$ and mild acid (Wingert \& Cheng, 1984).

$\ddagger$ Equation for the calculation of the apparent velocity for the one-enzyme-two-activities system (Dixon \& Webb, 1964) is shown below:

$$
v=\frac{V_{1}\left(\left[\mathrm{~S}_{1}\right] / K_{1}\right)+V_{2}\left(\left[\mathrm{~S}_{2}\right] / K_{2}\right)}{1+\left(\left[\mathrm{S}_{1}\right] / K_{1}\right)+\left(\left[\mathrm{S}_{2}\right] / K_{2}\right)}
$$

where $v, V,[\mathrm{~S}]$ and $K$ are apparent velocity, maximal velocity, substrate concentration and Michaelis constant respectively. 1 and 2 represent the acceptors FPDG and $\mathrm{IO}_{4}{ }^{-}-\mathrm{PSM}$ respectively. $V_{1}=37.3 \mathrm{nmol} / \mathrm{h}$ per $\mathrm{mg}$ of protein $V_{2}=14.5 \mathrm{nmol} / \mathrm{h}$ per $\mathrm{mg}$ of protein $K_{1}=0.94 \mathrm{mM} ; K_{2}=0.19 \mathrm{~mm}$. The kinetic constants were obtained from Expts. 1-6.

$\S$ The sum of apparent velocities obtained from the results of assaying the enzyme activity in the presence of each acceptor separately.

$N$-acetylglucosamine and galactose was $1.00: 1.14$, indicating that only one $\mathrm{N}$-acetylglucosamine residue was transferred to the disaccharide. The newly formed $N$-acetylglucosaminide was completely cleaved by jack-bean $\beta$-hexosaminidase, further confirming its $\beta$-configuration.

\section{Acceptor competition study}

A mixed-acceptor experiment was carried out to determine whether the $N$-acetylglucosaminyltransferase is a mucin $\mathrm{N}$-acetylglucosaminyltransferase. The $\mathrm{IO}_{4}^{-}$-PSM was utilized as the mucin acceptor. The experimental conditions and results are shown in Table 1. The apparent velocities obtained from the mixed-acceptor experiment, as shown in Expts. $7-9$, were compared with the theoretical values calculated from the experimentally obtained data from single-acceptor Expts. 1-6. The experimentally obtained data agreed with those calculated for one enzyme system, indicating that the enzyme activity catalysing the reaction for both ac- ceptors is a mucin $N$-acetylglucosaminyltransferase.

\section{Discussion}

Previous reports on the respiratory (Boat et al., 1976; Lamblin et al., 1977) and intestinal (Wesley et al., 1983) mucins from patients with cystic fibrosis have described alteration in their chemical properties, namely an increase in more-acidic mucous glycoproteins that contain longer carbohydrate chains. This alteration may be explained by elevation of the relative activities between carbohydrate chain elongation versus chain-terminating enzymes in these two mucin-secreting tissues in patients with cystic fibrosis. Whether these changes are caused by the primary or secondary gene defects remains to be established. To date, there have been only limited studies on tracheal mucin glycosyltransferases (Baker \& Munro, 1971; Baker et al., 1972; Baker \& Sawyer, 1975; 
Mendicino et al., 1982; Cheng \& Bona, 1982; Sheares \& Carlson, 1983) but none on tracheal mucin $\mathrm{N}$-acetylglucosaminyltransferases.

In the present paper we describe a tracheal epithelial mucin $N$-acetylglucosaminyltransferase that catalyses the transfer of $N$-acetylglucosamine from UDP- $N$-acetylglucosamine to the C-6 of the $N$-acetylgalactosamine residue in the $\mathrm{Gal} \beta 1 \rightarrow$ 3GalNAc-R acceptor. In general, the enzymic properties of bovine tracheal mucin $N$-acetylglucosaminyltransferase are similar to those of the rabbit (Wingert \& Cheng, 1984) and dog (Williams \& Schachter, 1980; Williams et al., 1980) enzymes. To search for conditions that may be suitable for the purification of the membrane-bound $\mathrm{N}$-acetylglucosaminyltransferase, we subjected the microsomal membrane preparation to treatment with a variety of membrane-solubilizing agents. $\mathrm{N}$ Acetylglucosaminyltransferase was found to respond differently to various detergents. Triton $\mathrm{X}$ 100, Nonidet P-40 and Tween detergents (Fig. 1), grouped as type A non-ionic detergents (Helenius \& Simons, 1975), ranked the best among the detergents tested. However, the ability of the detergents to enhance activities did not correlate with the enzyme-solubilizing properties. For example, essentially no $\mathrm{N}$-acetylglucosaminyltransferase activity was extracted with Tween 20 (or Tweens 80 and 60 ), as was judged by assaying the enzyme activity in the $100000 \mathrm{~g}$ supernatant fraction and that in the pellet after detergent treatment (M. R. Little \& P. W. Cheng, unpublished work). Triton X-100 at $2 \%$ concentration, on the other hand, extracted approx. $50 \%$ of the enzyme activity from the microsomal membrane fraction. However, once the enzyme was solubilized it became extremely labile.

The structures of the mucin $\mathrm{N}$-acetylglucosaminides that have been elucidated to date include at least the following: GlcNAc $\beta 1 \rightarrow 3$ GalNAc (Lamblin et al., 1981), GlcNAc $\beta 1 \rightarrow 6$ GalNAc (Rovis et al., 1973; Newman \& Kabat, 1976; Kochetkov et al., 1976; Lamblin et al., 1981), GlcNAc $\beta 1 \rightarrow 3 \mathrm{Gal}$ (Rovis et al., 1973; Newman \& Kabat, 1976; Kochetkov et al., 1976), GlcNAc$\beta 1 \rightarrow 6 \mathrm{Gal}$ (Rovis et al., 1973), GlcNac $\beta 1 \rightarrow 4 \mathrm{Gal}$ (Newman \& Kabat, 1976; Kochetkov et al., 1976), GlcNAc $\alpha 1 \rightarrow 4$ Gal (Kochetkov et al., 1976) and GlcNAc $\alpha 1 \rightarrow 4$ GlcNAc (Newman \& Kabat, 1976). Only comparatively recently have the enzyme activities responsible for the synthesis of the $N$-acetylglucosaminide linkages of $\beta 1 \rightarrow 6$ to $N$-acetylgalactosamine (Williams \& Schachter, 1980; Wingert \& Cheng, 1984), $\beta 1 \rightarrow 3$ to $N$-acetylgalactosamine (Brockhausen et al., 1983b) and $\beta 1 \rightarrow 3$ to galactose (Brockhausen et al., 1983a) been reported in non-respiratory epithelial tissues. The $\beta 1 \rightarrow 6$ enzyme is the most active among the three $N$ acetylglucosaminyltransferases identified. The $\beta 1 \rightarrow 3$-linked galactose residue in the acceptor is required for the enzyme activity, since no enzyme activity was detected when asialo-OSM was used as the acceptor. The addition of an $N$-acetylglucosamine or galactose residue (Slomiany et al., 1984) will allow the chain to grow from galactose and/or $N$-acetylglucosamine ends. The formation of $\alpha 2 \rightarrow 6$ sialic acid linkage to the $N$-acetylgalactosamine residue will shut off the synthesis from the $N$ acetylglucosamine end, although it will not stop the elongation from the galactose end (Beyer et al., 1980). It is apparent that purification of the mucin $\beta-6-N$-acetylglucosaminyltransferase is necessary in order to study the acceptor specificity and to understand the regulation of mucous glycoprotein oligosaccharide synthesis.

The work was supported by National Institutes of Health Grant HL-30529, U.S. Public Health Service General Research Support Award 5-SO1-FR-05406, an R. J. Reynolds grant and a grant from the American Lung Association of North Carolina. We thank Dr. Y. T. Li, Dr. Arthur DeVries, Dr. Neil Jentoft and Dr. Thomas Gerken for providing the jack-bean $\beta$-hexosaminidase and FPDG and assistance in h.p.l.c. and ${ }^{1} \mathrm{H}$ n.m.r. studies respectively.

\section{References}

Allen, A. (1978) Br. Med. Bull. 34, 28-33

Baker, A. P. \& Munro, J. R. (1971) J. Biol. Chem. 246, 4358-4362

Baker, A. P. \& Sawyer, J. L. (1975) Biochem. Med. 14, 42-50

Baker, A. P., Sawyer, J. L., Munro, J. R., Weiner, G. P. \& Hillegass, L. M. (1972) J. Biol. Chem. 247, 51735179

Beyer, T. A., Rearick, J. I., Paulson, J. C., Prieels, J. P., Sadler, J. E. \& Hill, R. L. (1979) J. Biol. Chem. 254, 12531-12541

Beyer, T. A., Sadler, J. E. \& Hill, R. L. (1980) J. Biol. Chem. 255, 5364-5372

Beyer, T. A., Sadler, J. E., Rearick, J. I., Paulson, J. C. \& Hill, R. L. (1981) Adv. Enzymol. Relat. Areas Mol. Biol. 52, 22-175

Bjorndahl, H., Lindberg, B. \& Svensson, S. (1967) Acta Chem. Scand. 21, 1808-1814

Boat, T. F. \& Cheng, P. W. (1976) in Cystic Fibrosis: Projections into the Future (Mangos, J. A.\& Talamo, R. C., eds.), pp. 165-172, Stratton International Medical Co., New York

Boat, T. F., Cheng, P. W., Iyer, R., Carlson, D. M. \& Polony, I. (1976) Arch. Biochem. Biophys. 177, 95-104

Brockhausen, I., Rachaman, E. S., Matta, K. L. \& Schachter, H. (1983a) Carbohydr. Res. 120, 3-16

Brockhausen, I., Williams, D., Matta, K. L., Orr, J. \& Schachter, H. (1963b) Can. J. Biochem. Cell Biol. 61, 1322-1333

Carlson, D. M. (1968) J. Biol. Chem. 243, 616-626

Carlson, D. M., McGuire, E. J., Jourdian, G. W. \& Roseman, S. (1973) J. Biol. Chem. 248, 5763-5773

Cheng, P. W. \& Bona, S. J. (1982) J. Biol. Chem. 257, 6251-6258 
Daniel, P. F., DeFeudis, D. F., Lott, J. T. \& McCleur, R. H. (1981) Carbohydr. Res. 97, 161-180

de Salegui, M. \& Plonska, H. (1969) Arch. Biochem. Biophys. 129, 49-56

DeVries, A. L., Komatsu, S. K. \& Feeney, R. E. (1970) J. Biol. Chem. 245, 2901-2908

Dixon, M. \& Webb, E. C. (1964) The Enzymes, 2nd edn., pp. 84-86, Longmans, London

Faltynek, C. R., Silbert, J. E. \& Hof, L. (1981) J. Biol. Chem. 256, 7139-7141

Hakomori, S. (1964) J. Biochem. (Tokyo) 55, 205-208

Helenius A. \& Simons, K. (1975) Biochim. Biophys. Acta 352, 327-337

Hill, H. D., Reynolds, J. A. \& Hill, R. L. (1977) J. Biol. Chem. 252, 3791-3798

Kochetkov, N. K., Derevitskaya, V. A. \& Arbatsky, N. P. (1976) Eur. J. Biochem. 67, 129-136

Lamblin, G., Lhermitte, M., Lafittle, J. J., Filliat, M., Degand, P. \& Roussel, P. (1977) Bull. Eur. Physiopathol. Respir. 13, 175-181

Lamblin, G., Lhermitte, M., Boersma, A., Roussel, P., Van Halbeek, H., Dorland, L. \& Vliegenhart, J. F. G. (1981) Monogr. Paediatr. 14, 46-49

Li, S. C., Mazzotta, M. Y., Chien, S. F. \& Li, Y. T. (1975) J. Biol. Chem. 250, 6786-6791

Lin, Y. \& DeVries, A. (1974) Biochem. Biophys. Res. Commun. 59, 1192-1196

Lowry, O. H., Rosebrough, N. J., Farr, A. L. \& Randall, R. J. (1951) J. Biol. Chem. 193, 265-275

Mendicino, J., Sivikami, S., Davilla, M. \& Chandrasekaran, E. V. (1982) J. Biol. Chem. 257, 3987-3994
Newman, W. \& Kabat, E. A. (1976) Arch. Biochem. Biophys. 172, 535-550

Rose, M. D., Lynn, W. S. \& Kaufman, B. (1979) Biochemistry 18, 4030-4037

Roseman, S. (1970) Chem. Phys. Lipids 5, 270-280

Rovis, L., Anderson, B., Kabat, E. A., Gruezo, F. \& Liao, J. (1973) Biochemistry 12, 5340-5354

Schachter, H. (1978) in The Glycoconjugates (Horowitz, M. I. \& Pigman, W., eds.), vol. 2, pp. 87-181, Academic Press, New York

Sheares, B. T. \& Carlson, D. M. (1983) J. Biol. Chem. 258, 9893-9898

Slomiany, B. L., Zdebska, E. \& Slomiany, A. (1984) J. Biol. Chem. 259, 2863-2869

Stellner, K., Saito, H. \& Halomori, S. (1973) Arch. Biochem. Biophys. 155, 464-472

Van Halbeek, H., Dorland, L., Haverkamp, J., Veldink, G., Vliegenthart, J. F. G., Fournet, B., Ricart, G., Montreuil, J., Gathmann, W. D. \& Aminoff, D. (1981) Eur. J. Biochem. 118, 487-495

Wesley, A., Forstner, J., Oureski, R., Mantle, M. \& Forstner, G. (1983) Pediatr. Res. 17, 65-69

Williams, D. \& Schachter, H. (1980) J. Biol. Chem. 255, 11247-11252

Williams, D., Longmore, G., Matta, K. L. \& Schachter, H. (1980) J. Biol. Chem. 255, 11253-11261

Wingert, W. E. \& Cheng, P. W. (1984) Biochemistry 23, 690-697

Wrann, M. M. \& Tappy, H. (1978) Eur. J. Biochem. 92, 105-108 